\title{
MJN RELATIONSHIP BETWEEN COMMUNITY ATTITUDES AND FLOOD MITIGATION IN THE WELANG WATERSHED IN THE KARANGKETUG URBAN VILLAGE, PASURUAN CITY
}

\author{
Heri Suroso* Loeki Enggar Fitri, Yati Sri Hayati \\ Faculty of Medicine, Brawijaya University, Malang, Indonesia \\ *Corresponding Author's Email: herisos39@gmail.com
}

\begin{abstract}
Background: Indonesia is one of the areas classified as disaster prone area, because every year has increased between 1,500-2,000 times and most are hydro-meteorological disasters such as floods. Efforts to reduce threat to flood disasters are to do prevention, mitigation, and preparedness. Objective: To identify and analyze the relationship between community attitudes and flood mitigation in the Welang watershed in the Karangketug Urban Village, Pasuruan City. Methods: This study used an analytic observational design with a cross-sectional approach. The population was 143 householders and the samples were 105 householders living in the river flood disaster-prone areas Welang RW. 01 / RT. 02-03 Karangketug Urban Village, Pasuruan City. The sampling method is purposive sampling. The Spearman rank correlation test was used for data analysis with a significant level $(\alpha)=0.05$. Results: The Spearman Rank test correlation indicates that there is a significant correlation between attitude and the mitigation of floods $(p=0.000$ and $r=0.546)$. Conclusion: Personal factor such as attitude significantly correlate with community mitigation in the face of flood disasters in the Welang watershed in the Karangketug Urban Village, Pasuruan City.
\end{abstract}

Keywords: Attitude, Community Mitigation, Flood

\section{INTRODUCTION}

Lives of the people in the world are not going to be separated from the occurrence of a disaster, natural or non-natural. Law of the Republic of Indonesia Number 24 the Year 2007 Article 1, Paragraph 1 concerning disaster management, states that a disaster is a series of incidents or events that can threaten and disturb human life, caused by natural and non-natural factors, and human factors.

Indonesia is a country that has flood-prone areas, nationally in 2005-2015, an increase in hydrometeorological disasters occurred in Indonesia. The flooding incident in the capital city of Indonesia in January 2013 resulted in 40 deaths, 45,000 people were displaced, and substantial material damage occurred that caused a loss of Rp15 billion, while in 2014 the loss had reached Rp100 million per day ( Asdak, Supian \& Subiyanto, 2018).

Flood disasters occur due to extreme storms in the upper watersheds, climate change, and are influenced by geomorphological conditions of soil slopes, erosion and sediment material. Flood disasters will have an impact on social conditions, health status, deaths, and the economy of the community. Losses due to flooding include damage to houses which cause relatively high costs to recover damage, loss of crop yields, and uncertainty about the future directly or indirectly that will affect people's lives, and psychological conditions of the victims (Azmeri \& Isa, 2018).

Pasuruan City is one of the areas in East Java Province that has flood-prone areas, especially in the Welang watershed, Karangketug Kelurahan area, every time in the rainy season, floods occur frequently and in 2019 floods occur in Karangketug Kelurahan 6 times in January - April with the highest flood height reaching 120 $\mathrm{cm}$, whereas in 2018 flooding occurred 6 times in January and February with the highest flood reaching $110-220 \mathrm{~cm}$, there were 2 people injured and caused disruption to the 
transportation route between Surabaya - Probolinggo. Flood disasters that often occur in the Karangketug Village, Pasuruan require effective and efficient treatment. So the community need to play a vital and actively role in flood mitigation.

The disaster prevention phase is an effort to eliminate and reduce threats to disasters which include prevention, mitigation, and disaster preparedness activities. Disaster mitigation is an effort to reduce disaster risk, both through physical development as well as awareness and capacity building to face the threat of disaster by establishing disaster-prone zones and constructing buildings by government codes and regulations (Law No. 24 the Year 2007, Chapter I General Provisions, Article 1 paragraph 6 of PP No. 21 of 2008 concerning the Implementation of Disaster Management ( Kurniati, Trsyani \& Theresia, 2018). The behavior of a person in making decisions on mitigating household flood disasters individually is influenced by personal attitudes and values towards preparedness to face a disaster, if the community can do individual mitigation in the household, it will reduce the risk of floodings, such as minimizing the occurrence of casualties, loss of building infrastructure and housing facilities.

The purpose of disaster mitigation or disaster risk reduction is to decrease losses in the event of future hazards, reduce the risk of death and injury to the population, minimize damage and economic losses caused on public sector infrastructure and the private sector, and encourage people in the disaster area to protect themselves, especially those who live in watersheds that are vulnerable to flooding in the rainy season or floods caused by shipping from the highlands. So, the attitude of the individual community is expected to reduce the risk of disaster by taking disaster mitigation measures against flood individually in the household.

\section{METHODOLOGY}

\section{Study design}

This study uses an analytic observational design with a cross-sectional approach.

\section{Setting}

The study was conducted from February to March 2020 in Karangketug Urban Village, Pasuruan City which has a high level of vulnerability to flooding. The sampling method is purposive sampling. The instrument used in this study was a questionnaire.

\section{Research Subjects}

The population was 143 householders and the samples were 105 householders living in the river flood disaster-prone areas of Welang Rw. 01 / Rt. 02-03 Karangketug Urban Village, Pasuruan City. The sampling method is purposive sampling

\section{Instrument}

A modified instrument by Poussin, Botzen \& Aerts, (2014) and Botzen et al., (2019) was used to determine the community attitude. The instrument has good validity (r-corrected item-total correction $\geq 0.3$ ) and reliability (Cronbach alpha $=0.887)$. Attitude is considered good if the score $\geq 60 \%$ and poor if the score $\leq 60 \%$. While flood mitigation using research by Poussin, Botzen \& Aerts, (2014), was modified by the researcher to determine community mitigation flood with good validity ( $\mathrm{r}-$ corrected item-total correction $\geq 0.3$ ) and reliability $($ Cronbach alpha $=0.845)$. Community mitigation flood was considered good if the score $\geq 50 \%$ and poor if the score $\leq 50 \%$.

\section{Ethical consideration}

The study was examined and approved by the health research ethics committee of Brawijaya University, Malang.

\section{Data analysis}

There are two types of analysis, univariate and bivariate. Univariate analysis was carried out to identify the characteristics of respondents, while bivariate analysis was done to describe the relationship between community attitudes and flood mitigation using the Spearman Rank correlation test with a significant level $(\alpha)=0.05$.

\section{RESULTS}

\section{Distribution of General Characteristics of Respondents}

Based on the research that has been done following result were obtained

Table 1: Characteristics of Respondents by Age

\begin{tabular}{|l|c|c|c|c|c|}
\hline & N & Min & Max & The mean & S D \\
\hline Age & 105 & 29 & 69 & 48.19 & 11.17 \\
\hline
\end{tabular}


The age distribution shows that the average age of respondents was 48.19 years, where the youngest age was 29 years and the oldest age was 69 years with data distribution of 11.17.

Table 2: Characteristics of Respondents by Gender, Education, Profession, Length of Stay, Distance to Home, and Experience in Dealing with Floods

\begin{tabular}{|c|c|c|c|}
\hline No. & Characteristics & $\begin{array}{l}\text { Frequency } \\
\text { (n ) }\end{array}$ & $\begin{array}{c}\text { Percentage } \\
(\%)\end{array}$ \\
\hline 1 & $\begin{array}{l}\text { Gender } \\
\text { a. Male } \\
\text { b. Girl } \\
\text { c. Total }\end{array}$ & $\begin{array}{c}57 \\
48 \\
105 \\
\end{array}$ & $\begin{array}{c}54.3 \\
45.7 \\
100.0\end{array}$ \\
\hline 2 & $\begin{array}{l}\text { Education } \\
\text { a. No school } \\
\text { b. Primary School } \\
\text { c. Junior High School } \\
\text { d. Senior High School } \\
\text { e. Diploma / Bachelor } \\
\text { Degree } \\
\text { f. Total }\end{array}$ & $\begin{array}{c}9 \\
34 \\
18 \\
40 \\
4 \\
105\end{array}$ & $\begin{array}{c}8.6 \\
32.4 \\
17.1 \\
38.1 \\
3.8 \\
100.0\end{array}$ \\
\hline 3 & $\begin{array}{l}\text { Profession } \\
\text { a. Army, Police, } \\
\text { Entrepreneurs, Private } \\
\text { Employees. } \\
\text { b. Farmers, farm } \\
\text { laborers, factory } \\
\text { workers, odd jobs. } \\
\text { c. Does not work } \\
\text { d. Total }\end{array}$ & $\begin{array}{c}67 \\
1 \\
105 \\
\end{array}$ & $\begin{array}{c}35.2 \\
63.8 \\
1,0 \\
100.0 \\
\end{array}$ \\
\hline 4 & $\begin{array}{l}\text { Length of stay } \\
\text { a. }<1 \text { year } \\
\text { b. }>1 \text { year } \\
\text { c. Total }\end{array}$ & $\begin{array}{c}0 \\
105 \\
105\end{array}$ & $\begin{array}{c}0.0 \\
100.0 \\
100.0\end{array}$ \\
\hline 5 & $\begin{array}{l}\text { Home Distance } \\
\text { a. }<10 \text { meters } \\
\text { b. } 10-15 \text { meters } \\
\text { c. }>15 \text { meters } \\
\text { d. Total }\end{array}$ & $\begin{array}{c}21 \\
20 \\
64 \\
105\end{array}$ & $\begin{array}{c}20.0 \\
19.0 \\
61.0 \\
100.0 \\
\end{array}$ \\
\hline 6 & $\begin{array}{l}\text { Experiences Facing a Flood } \\
\text { a. Has never been } \\
\text { b. } 1 \text { time } \\
\text { c. }>1 \text { time } \\
\text { d. Total }\end{array}$ & $\begin{array}{c}0 \\
0 \\
105 \\
105\end{array}$ & $\begin{array}{c}0.0 \\
0.0 \\
100.0 \\
100.0\end{array}$ \\
\hline
\end{tabular}

Based on table 2 it showed that most respondents are male $(54.3 \%)$, nearly half of respondents were educated upto SMA (38.1\%), most respondents work as farmers, farm laborers, factory workers $63.8 \%$ odd jobs, all respondents live in the Karangketug Urban Village for more than 1 year $(100 \%)$, most respondents have a distance of more than 15 meters from the river flow (61\%) and all respondents have experience dealing with floods more than 1 times $(100 \%)$.
Table 3: Distribution of Respondents by Attitude

\begin{tabular}{|l|c|c|}
\hline Attitude & Frequency (n) & Percentage (\%) \\
\hline Good & 71 & 67.6 \\
Poor & 34 & 32.4 \\
Total & 105 & 100.0 \\
\hline
\end{tabular}

Based on table 3 it was found that the majority of respondents had a good attitude towards flood disaster mitigation $(67.6 \%)$. Based on the results of the study it was found that the attitude and concern of the community in the Karangketug Urban Village, Pasuruan City is good. This can be seen from several aspects of flood disaster mitigation in the community individually in the house, especially in the aspect of elevating the ground floor from the potential for flooding, equipment, and waterproof building walls, electrical systems above the potential for flooding, drainage installation, and adjustments to the household furniture.

Table 4: Distribution of Respondents Based on Flood Mitigation

\begin{tabular}{|c|c|c|}
\hline $\begin{array}{l}\text { Flood Disaster } \\
\text { Mitigation }\end{array}$ & Frequency (n ) & Percentage (\%) \\
\hline Good & 44 & 41.9 \\
Poor & 61 & 58.1 \\
Total & 105 & 100.0 \\
\hline
\end{tabular}

Based on table 4 it was found that the majority of respondents had less mitigation against flooding, which are 61 respondents $(58.1 \%)$. Based on the results of the study it was found that the mitigation of the community in the Karangketug Urban Village of Pasuruan City against flooding was lacking, this can be seen from several aspects of flood disaster mitigation to the community individually in the house, especially in aspects of elevating the ground floor, making sandbags as mini dams and making systems drainage in the house.

\section{Bivariate Analysis}

Relationships between Public Attitudes with Flood Disaster Mitigation in Watershed (DAS) Welang Karangketug Urban Village Pasuruan City.

Table 5: Relationship between Community Attitudes and Flood Mitigation in Watersheds Welang Karangketug Urban Village, Pasuruan City

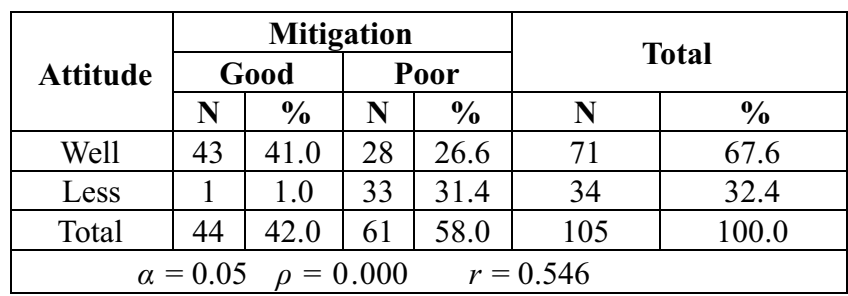


Based on table 5, the results of the analysis of the relationship between community attitudes and flood disaster mitigation show 71 respondents have a good attitude, almost half of respondents have good flood disaster mitigation (41\%). While 34 respondents have poor attitude, almost all (33 of 34) respondents or onethird of all respondents (31.4\%) have less flood mitigation. Statistical test results obtained a significant value of 0.000 ( $p$ value <0.05), then $\mathrm{H} 0$ is rejected, which means there is a significant relationship between community attitudes with flood disaster mitigation. The results of the correlation coefficient ( $r$ count) 0.546, means the strength of the correlation of the two variables is present.

\section{DISCUSSION}

\section{Relationship between Community Attitudes and Flood Mitigation in Watersheds Welang Karangketug Urban Village, Pasuruan City}

The results of the bivariate analysis showed that community attitudes had a significant relationship with flood disaster mitigation in the watersheds of the Welang Karangketug Urban Village, Pasuruan City, and the strength of the correlation between the two variables was moderate. The results of the univariate analysis showed that the majority of respondents $(67.6 \%)$ had a good attitude towards flood disaster mitigation, especially in the aspect of flood disaster mitigation in the community individually at home. This can be seen from several aspects of flood disaster mitigation in the community individually in the home especially in the aspect of elevating the ground floor from flooding, waterproof building equipment, and walls, electrical systems above the potential for flooding, drainage installation, and adjusting household furniture.

The results of this study are in line with studies conducted by Bubeck et al., (2012), which states that risk attitude influences one's decision making in carrying out individual flood disaster mitigation measures. The results of this study are also consistent with research conducted by Viglione et al., (2014), which explains that attitudes have a role in the decision to move - structural measures of flood disaster risk reduction. Bempah \& Olav Øyhus (2017) revealed that attitude is one of the factors that influence a person's behavior in carrying out disaster mitigation measures related to environmental hazards. This is by the opinion of Wicaksono \& Pangestuti (2019), that attitudes can change the mindset of a person both individually and in groups in mitigating disasters with various measures of activity, such as building waterproof buildings, understand the characteristics of water and keep the environment clean and comfortable.

Poussin et al., (2014), stated that attitude is one of the factors that influence the implementation of flood mitigation measures in households. Giesen et al., (2015), stated that a good attitude is a person's acceptance and interest in an object in solving a problem with good responsibility. This is according to research conducted by Notoatmodjo (2012), that attitude has four levels, namely receiving (receiving), respond (responding), respect (valuing), and responsible (Responsible). The accepting phase is that a person has an interest in solving a problem by taking steps to mitigate floods as an individual disaster management effort. Respond is someone individually willingness and able to take steps to mitigate floods in the household. Respect that someone actively invites family and neighbors to increase flood disaster relief efforts by taking individual mitigation measures in the household. Responsible is that someone is able to mitigate flood disasters individually in the household seriously to reduce the impact caused by flood disasters.

Attitude is an individual's willingness to behave or take action. Attitudes are formed through several factors, such as education, knowledge, and experience (Odulana et al., 2015). Tuhusetya (2012), stated that in the formation of good attitudes of a person is strongly influenced by education and knowledge. Disaster education has the aim to foster an attitude of alertness, responsive, and responsive to a disaster. A good attitude towards a disaster is expected to be able to provide an understanding of the concepts and hazards of a disaster, as well as being able to carry out disaster management efforts by implementing disaster mitigation and preparedness measures. Univariate analysis results found that $38 \%$ of the people living in the Welang watershed, Karangketug Urban Village, Pasuruan City had a high school education and $74.2 \%$ had good knowledge about flood disaster mitigation. Knowledge about the occurrence of disasters can be obtained through existing resources in the community by attending training related to disaster management and participating in disaster preparedness communities.

van Giesen et al., (2015) revealed that in addition to education and knowledge, the formation of one's attitude 
in general, is built by earlier experience. The univariate analysis results found that $100 \%$ of the people living in the Welang watershed of the Karangketug Urban Village in Pasuruan city had experienced flooding more than once and $100 \%$ of the people living in the Welang watershed of the Karangketug Urban Village of Pasuruan City for more than one year.

A person's attitude to danger is generally shown by one's optimism (the belief that the danger of disaster will not happen to me), self-confidence or illusion control (I can overcome the danger that will happen to me), and immunity (a danger that occurs cannot be dangerous myself) (Ahmad et al., 2017). The attitude of the societies in implementing flood mitigation individually, are formed due to the perception and awareness of the dangers caused by the disaster so that the community will tend to make efforts to minimize the impact caused by a disaster (Robinson \& Botzen, 2019). The attitude of the societies towards mitigating flood disasters individually is influenced by knowledge of the occurrence of disasters and the impact that are caused by a disaster. Attitude has a very important role in community behavior in implementing flood disaster mitigation individually in the household to save themselves and their families from disasters. A good attitude towards disasters will make someone better prepared to face disasters.

\section{CONCLUSION}

There is significant coordination of community attitude and mitigation of flooding in the Welang Watershed in the Karangketug Urban Village, Pasuruan City. The degree of the correlation was positive, which indicated that the higher the community attitude, the more preparation they would have for flood disaster. From this study, it is expected that the community can improve a good attitude towards disaster management using training, counseling, and seminars on disaster management organized by the government or non-government.

For the government and the Pasuruan City BPBD, it is hoped that the positive attitude of the community in implementing individual disaster mitigation in the household be improved by utilizing the knowledge, abilities or trust of the people involved in the implementation of flood disaster mitigation so that the community has good preparedness in facing flood disasters.

\section{Conflict of Interests} interest.

The authors declare that they have no conflict of

\section{ACKNOWLEDGEMENT}

The authors would like to thank the nursing students who participated in this study for their time and patience.

\section{REFERENCES}

Ahmad, S. L., Ahsan. \& Fathoni, M. (2017). Analisis Faktor Yang Berhubungan Dengan Kesiapsiagaan Keluarga Dalam Menghadapi Bencana Di Kota Ternate Propinsi Maluku Utara. Universitas Brawijaya, Philippines.

Asdak, C., Supian, S. \& Subiyanto (2018). Watershed management strategies for flood mitigation: A case study of Jakarta's flooding. Weather and Climate Extremes, 21(September 2017), pp 117-122.

Azmeri, A. \& Isa, A. H. (2018). An analysis of physical vulnerability to flash floods in the small mountainous watershed of Aceh Besar Regency, Aceh province, Indonesia. Jamba: Journal of Disaster Risk Studies, 10(1), pp $1-6$.

Bempah, S. A. \& Øyhus, A. O. (2017). The role of social perception in disaster risk reduction: Beliefs, perception, and attitudes regarding flood disasters in communities along the Volta River, Ghana. International Journal of Disaster RiskReduction, 23, pp 104-108.

Botzen, W. W., Kunreuther, H., Czajkowski, J. \& de Moel, H. (2019). Adoption of Individual Flood Damage Mitigation Measures in New York City : An Extension of Protection Motivation Theory. Risk, 39(10), pp 2143-2159.

Bubeck, P., Botzen, W. J. W., Kreibich, H. \& Aerts, J. C. J. H. (2012). Long-term development and effectiveness of private flood mitigation measures: an analysis for the German part of the river Rhine. Natural Hazards and Earth System Sciences (NHESS), 12(11), pp 3507-3518.

Kurniati, A., Trsyani, Y. \& Theresia, S. I. M. (2018). Keperawatan Gawat Darurat dan Bencana Sheehy. 1 Indonesi. 
Singapore: Elsevier Ltd.

Notoatmodjo, S. (2012). Metodologi Penelitian Kesehatan. Jakarta: Rineka Cipta.

Odulana, A., Kim, M. M., Green, M., Taylor, Y., Howard, D. L., Godley, P. \& Corbie-Smith, G. (2014). Participating in research: attitudes within the African American church. Journal of religion and health, 53(2), pp 373-381.

Poussin, J. K., Botzen, W. J. W. \& Aerts, J. C. J. H. (2014). Factors of influence on flood damage mitigation behavior by households. Environmental Science and Policy, 40, pp 1-9.

Robinson, P. J. \& Botzen, W. J. W. (2019). Determinants of Probability Neglect and Risk Attitudes for Disaster Risk : An Online Experimental Study of Flood. Risk Analysis, 39(11), pp 2514-2527.

Tuhusetya, S. (2012). Pendidikan Kebencanaan dan Kesigapan Mengurangi Risiko. Retrieved from: http://sawali.com (Accessed: 21 March 2020).

van Giesen, R. I., Fischer, A. R., Van Dijk, H. \& Van Trijp, H. C. (2015). Affect and cognition in attitude formation toward familiar and unfamiliar attitude objects. PloS One, 10(10), e0141790.

Viglione, A., Di Baldassarre, G., Brandimarte, L., Kuil, L., Carr, G., Salinas, J.L., Scolobig, A. \& Blöschl, G. (2014). Insights from socio-hydrology modelling on dealing with flood risk-roles of collective memory, risk-taking attitude and trust. Journal of Hydrology, 518, pp 71-82.

Wicaksono, R. D. \& Pangestuti, E. (2019). Analisis Mitigasi Bencana Dalam Meminimalisir Risiko Bencana (Study pada Kampung Wisata Jodipan Kota Malang). Journal Administrasi Bisnis (JAB), 71(1), pp 8-17. 